\title{
EKUITAS MEREK DAN KEPUTUSAN PEMBELIAN: STUDI PADA KONSUMEN ANAK USIA SEKOLAH DASAR DI KOTA DEPOK
}

\author{
Endah Meiria \\ UIN Syarif Hidayatullah Jakarta \\ endah.meiria@gmail.com
}

\begin{abstract}
This study aims to identify: how brand equity's factors of Biskuat and purchase decision of this biscuit by children consumer at the elementary school age in Depok City, as well as how the influence of brand equity's factors of Biskuat towards purchase decision of this biscuit by children consumer at the elementary school age in Depok City. The object of this study is brand awareness, brand association, perceived quality, brand loyalty and purchase decision. The study was conducted in six sub-district of Depok City, with 100 children as the respondent from several schools and environments in six sub-district of Depok City.Testing hypotheses using path analysis (path analysis), which is equipped with testing the validity and reliability. Based on the analysis of the model lines of research, obtained results that brand equity which is brand awareness, brand association, perceived quality, and brand loyalty in partially and simultaneously has significantly affect to purchase decision.
\end{abstract}

Keywords: brand equity, purchace decision, elementary school consumer

\begin{abstract}
Abstrak
Penelitian ini bertujuan untuk mengidentifikasi : bagaimana faktor-faktor ekuitas merek Biskuat dan keputusan pembelian biskuit ini oleh anak usia sekolah dasar di Kota Depok, serta bagaimana pengaruh faktor-faktor ekuitas merek Biskuat terhadap keputusan pembelian biskuit oleh anak usia sekolah dasar di Kota Depok. Objek penelitian ini adalah kesadaran merek, asosiasi merek, kesan kualitas, dan kesetiaan merek terhadap keputusan pembelian. Penelitian dilakukan di enam kecamatan di Kota Depok, dengan jumlah responden 100 orang anak pada beberapa sekolah dan lingkungan di enam kecamatan di Kota Depok. Pengujian hipotesis menggunakan analisis jalur (path analysis) yang dilengkapi dengan pengujian validitas dan reliabilitas. Berdasarkan analisis jalur terhadap model penelitian, diperoleh hasil bahwa ekuitas merek, yaitu kesadaran merek, asosiasi merek, kesan kualitas, dan kesetiaan merek baik secara parsial maupun simultan berpengaruh signifikan terhadap keputusan pembelian.
\end{abstract}

Kata Kunci: ekuitas merek, keputusan pembelian, konsumen anak usia sekolah dasar

Diterima: 30 Januari 2017; Direvisi: 14 Februari 2017; Disetujui: 27 Februari 2017 


\section{PENDAHULUAN}

Anak-anak adalah pasar yang sangat menjanjikan di masa kini dan masa depan. Berdasarkan data dari Badan Pusat Statistik tahun 2009, jumlah anak usia 014 tahun mencapai 63,5 juta orang, atau hampir 30\% jumlah penduduk Indonesia. Jumlah itu terbagi: usia 0-4 tahun sebanyak 19,60 juta $(9,4 \%)$, usia $5-9$ tahun 22,12 juta $(10,14 \%)$, dan usia $10-14$ tahun 21,85 juta $(10,2 \%)$. Data tersebut untuk tahun ini diperkirakan sudah berubah bahkan bisa saja semakin besar jumlahnya. Jika diambil persentasenya, bahwa jumlah anak di Indonesia adalah 30\% dari total populasi penduduk, maka jumlah anak termasuk pasar yang sangat potensial bagi produk-produk bisnis.

Pasar anak memiliki kecenderungan lebih mengutungkan karena relatif tidak sensitif terhadap harga. Segmen pasar ini anak-anak bisa memainkan tiga peran sekaligus, yaitu anak-anak berperan sebagai primary market, secondary market (influencer), dan juga future market (McNeal, 1992). Sebagai pasar primer, sekarang anak-anak sudah mulai melakukan aktivitas pembelian produk-produk tertentu (berperan sebagai pembeli) dalam keseharian mereka. Misalnya membeli sendiri makanan kecil di sekolah dengan uang jajannya, dimana anak bisa berperan sebagai pembeli utama atas merek-merek tertentu. Potensi pasar anak sebagai pasar primer memang tidak begitu besar jika mengandalkan uang saku mereka.

Pada pasar sekunder atau influencer, anak-anak mempunyai peran yang paling besar, di mana mereka dapat membujuk dan mempengaruhi orang tua atas pembelian suatu produk sampai jutaan rupiah atau bahkan mempengaruhi pilihan orang tua itu sendiri dalam menentukan produk yang meraka butuhkan dalam keluarga, misalnya pembelian televisi dan mobil. Hal ini senada dengan yang dikemukakan Lindstorm (2007) bahwa anak-anak mempengaruhi 60\% belanja keluarga; dan pelanggan muda tidak hanya mempengaruhi pembelanjaan keluarga untuk barang-barang seperti sarapan, melainkan juga untuk barang-barang penting seperti mobil, fashion dewasa, dan memiliki implikasi pemasaran yang besar. Ketiga, anak juga merupakan pasar masa depan (future market) yang menjanjikan. Proyeksi ini juga dikaitkan dengan peran mereka sebagai pengambil keputusan di masa yang akan datang. Misalnya, anak-anak yang ketika masih kecil membaca 
majalah Bobo, mempunyai kecenderungan ketika mereka mempunyai anak, mereka akan memberikan majalah yang sama pada anak mereka.

Dahulu orang tua sangat mempengaruhi pola konsumsi anak, baik secara langsung maupun tidak langsung. Mereka dengan sengaja mengajarkan pola konsumsi mereka kepada anaknya. Di samping itu, orang tua juga menentukan seberapa besar derajat toleransi anak untuk terekspos oleh sumber-sumber informasi lain, seperti televisi, salesman, dan teman sepermainan. Namun kini, dominasi orang tua dalam pemberian produk anak mulai berkurang (kecuali produk-produk yang berkaitan dengan kesehatan dan pendidikan). Hal ini disebabkan oleh beberapa hal yaitu: Pertama, masalah pendidikan. Pendidikan sekarang sudah menerapkan komunikasi dua arah, dimana ada interaksi langsung dengan anak-anak sehingga mereka merasa lebih percaya diri dalam mengambil keputusan. Demikian pula dengan orang tua yang makin sadar bahwa anak dibebaskan untuk mengambil keputusan supaya lebih cepat belajar. Kedua, masalah sosial ekonomi. Karena sosial ekonominya makin membaik biasanya anak-anak lebih punya keberanian untuk mengambil keputusan dan didukung pula dengan peran orang tuanya. Ketiga, jumlah anak sedikit, jadi membuat anak-anak dibebaskan untuk mengambil keputusan sendiri. Keempat, dual working family, di mana ada dua pendapatan karena ayah dan ibu sama-sama bekerja, terutama di daerah perkotaan. Kesibukan kedua orang tua menjadikan anak mendapatkan kebebasan membuat keputusan (Schiffman dan Kanuk, 2010). Walaupun anak-anak bukanlah pengambil keputusan utama dan bukan yang mempunyai uang sendiri, tetapi mereka tetap memegang peranan dalam memilih segala produk yang mereka inginkan dan mempunyai kekuatan membeli yang besar dari orang tua dan semua orang terdekatnya.

Salah satu produk makanan yang dikenali dan digemari oleh sebagian besar anak-anak adalah biskuit. Biskuit sering dijadikan sebagai makanan selingan oleh anak-anak maupun sebagai penuda rasa lapar. Biskuit Biskuat, sebagai salah satu pemain di pasar biskuit Indonesia yang menampilkan ikon macannya yang "eye catching" membuat merek biscuit ini cukup populer di kalangan anak-anak. Ikon macan ini dianggap sebagai asosiasi simbol kekuatan yang digunakan untuk 
memperkuat positioning Biskuat sebagai pionir biskuit bernutrisi untuk anak, dengan karakter utama segmen pasar biskuit ini adalah ibu dan anak yang menginginkan produk yang bervariasi dengan rasa yang enak dan bervariasi pula. Begitu juga dengan tag line-nya sebagai "Biskuit Juara”, "Tenaga Sekuat Macan”, dan "Semua Bisa Jadi Macan" yang terdengar cukup familiar yang dapat menimbulkan asosiasi biscuit yang bisa membuat tenaga menjadi kuat seperti symbol Biskuat dengan binatang nan buas seperti yang ditampilkan di media televisi maupun kemasannya. Hal ini merupakan bagian dari brand building produk untuk menciptakan image dan membangun ekuitas merek itu sendiri.

Penggunaan endorser bintang atlet olah raga yang juga 'kuat' seperti Bambang Pamungkas sampai Cesc Fabregas, pemain sepak bola dari Spanyol merupakan image tersendiri bagi Biskuat sebagai biscuit penambah energy sehingga dapat 'kuat' seperti para endorser. Penggunaan endorser sebagai role model ini dapat mewarnai perilaku anak-anak terhadap merek yang diiklankan (Ross and Harradine, 2004). Biskuat yang selama dua tahun berturut-turut sebagai pemegang Top Brand for Kids kategori biskuit anak dapat dijadikan objek penelitian bagaimana mereka membangun merek dan brand equity-nya sehingga dekat dengan anak-anak dan dapat mempengaruhi pengambilan keputusan pembelian biskuit ini baik dari sisi anak sebagai self buyer maupun orang tua dalam mendukung keputusan pembelian dan pengambil keputusan utama untuk membeli biskuit ini. Di Kota Depok sebagai area penelitian, minat dan pengetahuan merek Biskuat pada anak-anak ini cukup besar. Mereka mengetahui benar tentang Biskuat mulai dari kemasan, logo, iklan sampai endorser Biskuat, dan Biskuat ini cukup aktif mengadakan acara-acara yang melibatkan anak-anak baik di sekolah maupun di toko/supermarket sebagai publisitas dan promosi mereka, ditambah dengan prestasi Biskuat sebagai Top Brand biscuit anak-anak membuat Biskuat makin 'buas' di kalangan anak-anak. Selain itu, hampir setiap warung/toko bahkan kantin sekolah yang didatangi menjual biskuit ini sehingga dalam hal mendapatkan Biskuat menjadi mudah bagi anak-anak. Hal inilah yang ingin diteliti, faktor mana yang melekat pada Biskuat ini yang menjadikannya begitu dikenal dan membuat anakanak melakukan pembelian terhadap biscuit ini. 
Berikut adalah hasil survey Top Brand for Kids kategori biscuit anak-anak tahun 2009 dan 2010:

Tabel 1

Top Brand Index for Kids 2009-2010

\begin{tabular}{|c|c|c|c|c|c|c|c|}
\hline \multicolumn{4}{|c|}{ Indeks Gabung } & \multicolumn{4}{|c|}{ Indeks Gabung } \\
\hline Merek & $\begin{array}{c}\begin{array}{c}\text { Panel } \\
\text { Ibu }\end{array} \\
22.4 \%\end{array}$ & $\begin{array}{c}\text { Panel } \\
\text { Anak } \\
77.6 \%\end{array}$ & TBI & Merek & $\begin{array}{c}\text { Panel } \\
\text { Ibu } \\
20.2 \\
\%\end{array}$ & $\begin{array}{c}\text { Panel } \\
\text { Anak } \\
79.8 \%\end{array}$ & TBI \\
\hline & & & & & 28.2 & & \\
\hline Biskuat & $20.8 \%$ & $26.8 \%$ & $25.4 \%$ & Biskuat & $\%$ & $39.1 \%$ & $36.9 \%$ \\
\hline Roma & $10.4 \%$ & $8.7 \%$ & $9.1 \%$ & Oreo & $\begin{array}{c}7.9 \% \\
15.4\end{array}$ & $13.8 \%$ & $12.6 \%$ \\
\hline Oreo & $5.3 \%$ & $7.7 \%$ & $7.1 \%$ & Roma & $\%$ & $8.3 \%$ & $9.7 \%$ \\
\hline Better & $3.1 \%$ & $7.4 \%$ & $6.4 \%$ & $\begin{array}{l}\text { Better } \\
\text { Good }\end{array}$ & $5.7 \%$ & $8.3 \%$ & $7.8 \%$ \\
\hline Good Time & $4.9 \%$ & $4.2 \%$ & $4.3 \%$ & Time & $5.3 \%$ & $6.0 \%$ & $5.8 \%$ \\
\hline Tim Tam & $1.0 \%$ & $4.3 \%$ & $3.6 \%$ & $\begin{array}{l}\text { Trenz } \\
\text { Khon }\end{array}$ & $1.7 \%$ & $4.8 \%$ & $4.1 \%$ \\
\hline Khon Guan & $8.0 \%$ & $2.2 \%$ & $3.5 \%$ & Guan & $9.7 \%$ & $1.4 \%$ & $3.1 \%$ \\
\hline $\begin{array}{l}\text { Monde } \\
\text { Marie }\end{array}$ & $6.6 \%$ & $2.3 \%$ & $3.3 \%$ & $\begin{array}{l}\text { Monde } \\
\text { Roma }\end{array}$ & $4.3 \%$ & $1.9 \%$ & $2.4 \%$ \\
\hline $\begin{array}{l}\text { Regal } \\
\text { Roma }\end{array}$ & $7.3 \%$ & $2.0 \%$ & $3.2 \%$ & Kelapa & $4.1 \%$ & $1.7 \%$ & $2.2 \%$ \\
\hline Kelapa & $3.6 \%$ & $2.2 \%$ & $2.3 \%$ & Nissin & $1.9 \%$ & $1.1 \%$ & $1.3 \%$ \\
\hline
\end{tabular}

Berdasarkan beberapa penelitian mengenai ekuitas merek dengan objek penelitian yang berbeda-beda di mana respondennya adalah orang dewasa, hasil penelitian menunjukkan bahwa setiap variabel ekuitas merek memberikan pengaruh yang berbeda-beda terhadap objek tertentu. Beberapa penelitian mengenai merek dan perilaku pembelian anak-anak juga menunjukkan bahwa anak-anak sudah mempunyai kekuatan sendiri dalam memandang, memilih, dan membeli produk tertentu. Seperti dalam jurnal yang diungkapkan oleh John (1999) bahwa dalam setiap tahap perkembangannya anak-anak sudah mempunyai pengetahuan mengenai produk, merek, iklan, belanja, harga, strategi dalam pengambilan keputusan, strategi mempengaruhi orang tua, dan motif dalam 
mengkonsumsi dan nilainya. Sebagai pemeran utama, anak-anak yang akan dilibatkan sebagai responden mengenai ekuitas merek akan menjadi sesuatu yang menarik untuk diteliti, karena anak-anak sekarang menghabiskan lebih banyak waktu dalam setting komersial seperti berbelanja di toko dan telah dikelilingi oleh pesan-pesan komersial dalam berbagai macam bentuk (Dotson dan Hyatt, 2005). Maka, dengan stimulus yang mereka rasakan tiap harinya, secara sadar maupun tidak sadar dengan apapun istilahnya, anak-anak telah terlibat dalam menilai ekuitas merek dari produk-produk yang dipilihnya.

Berdasarkan latar belakang dan hasil penelitian yang pernah dilakukan, populasi penelitian yang akan diteliti adalah anak-anak sekolah dasar pada enam kecamatan di wilayah Kota Depok untuk melihat bagaimana ekuitas merek Biskuat mempengaruhi pengambilan keputusan pembelian mereka.

\section{METODE}

Metode penelitian yang digunakan adalah metode deskriptif dan metode verifikatif. Penelitian deskriptif ini digunakan untuk menganalisa tingkat kesadaran merek, kesetiaan merek, kesan kualitas dan asosiasi merek biskuat terhadap keputusan pembelian oleh konsumen anak sekolah dasar di Kota Depok. Populasi dalam penelitian ini adalah anak-anak di sekolah dasar pada enam kecamatan Kota Depok, di mana keseluruhan populasi berjumlah 132.783 orang. Metode yang digunakan untuk penarikan sampel adalah proportionate stratified random sampling, yaitu pengambilan sampel dari anggota populasi secara acak dan berstrata secara proporsional (Sugiyono, 2011). Selanjutnya sampel ditarik secara random dari setiap kelompok sehingga bisa meliputi setiap strata yang berbeda untuk mewakili populasi secara keseluruhan. Teknik pengambilan sample menggunakan rumus dari Taro Yamane (Riduwan, 2009) sehingga diperoleh jumlah sampel sebanyak 100 orang. Teknik pengumpulan data dilakukan dengan observasi, wawancara, dan kuesioner.

Metode analisis dalam penelitian ini menggunakan analisis korelatif yang dilanjutka dengan analisis jalur (Path Analysis). Pada teknik analisis jalur memerlukan syarat data yang mempunyai tingkat pengukuran sekurang-kurangnya interval, jadi untuk keperluan tersebut data ordinal yang diperoleh dari kuesioner 
terlebih dahulu dikonversi menjadi data interval menggunakan Methods of Successive Interval (MSI) dengan bantuan program statistic metode interval.

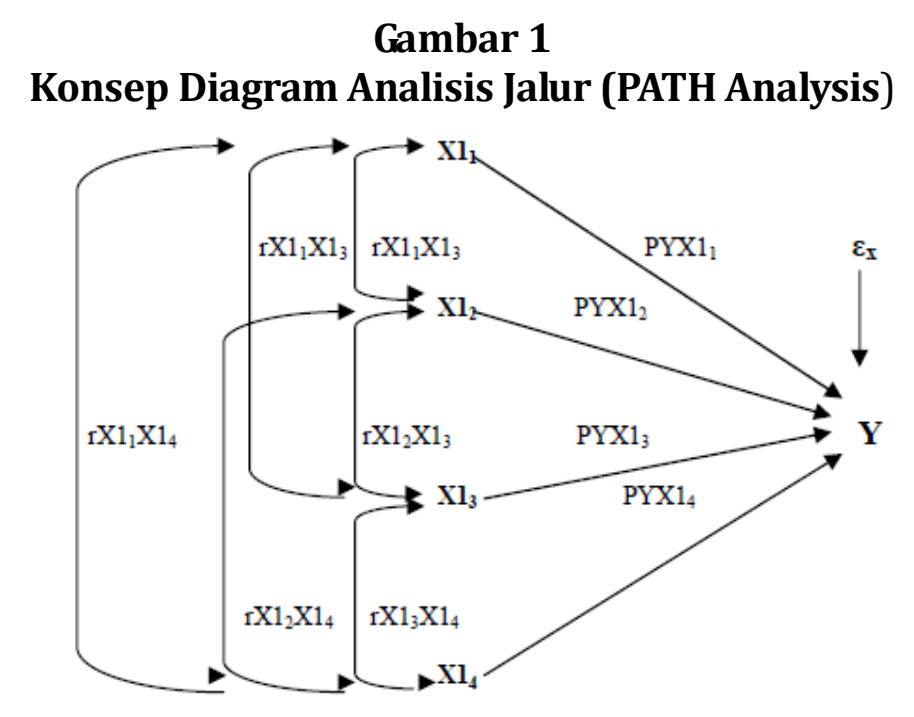

Berdasarkan Gambar 1, maka persamaan struktural yang dapat dibuat adalah:

$$
\mathrm{Y}=\mathrm{PYX1} 1_{1}+\mathrm{PYX1} 1_{2}+\mathrm{PYX1} 1_{3}+\mathrm{PYX} 1_{4}+\mathrm{Py \varepsilon}
$$

Dimana: Y ialah keputusan pembelian; $\mathrm{X} 1_{1}$ ialah Kesadaran merek; $\mathrm{X} 1_{2}$ ialah Asosiasi merek; $\mathrm{X} 1_{3}$ ialah Kesan kualitas; $\mathrm{X} 1_{4}$ ialah Kesetiaan merek

\section{HASIL DAN PEMBAHASAN PEMBAHASAN}

\section{Hasil}

Untuk mengetahui tingkat kesadaran merek, asosiasi merek, kesan kualitas, kesetiaan merek, dan keputusan pembelian oleh anak di Kota Depok, akan dilakukan pengkategorian berdasarkan pengolahan skor setiap pertanyaan pada masingmasing variabel yang diamati, kemudian dicari panjang interval setiap kelas. Tabel 2 memperlihatkan tanggapan responden tentang kesadaran merek secara keseluruhan, dan dapat dinyatakan bahwa kesadaran merek Biskuat pada anak di Kota Depok adalah tinggi yang terlihat dari mayoritas responden yaitu sebanyak 68 orang atau 68\% memiliki tanggapan terhadap kesadaran merek termasuk dalam kategori tinggi. Dalam hal ini, anak-anak cenderung membeli Biskuat karena mereknya sudah mereka kenal dan mereka dengan mudah bisa mengingat merek ini melalui warna, rasa, karakter, tokoh, dan lain-lain. 
Tabel 2. Kategorisasi Variabel Kesadaran Merek

\begin{tabular}{rccc}
\hline Sub Variabel & Kategori & Frekuensi (orang) & Persentase \\
\hline \multirow{3}{*}{ Kesadaran Merek $\left(X 1_{1}\right)$} & Tinggi & 68 & $68,00 \%$ \\
& Cukup Tinggi & 18 & $18,00 \%$ \\
& Kurang Tinggi & 14 & $14,00 \%$ \\
Total & & $\mathbf{1 0 0}$ & $\mathbf{1 0 0 , 0 0 \%}$ \\
\hline
\end{tabular}

Sumber : Hasil Pengolahan Data Penelitian

Tabel 3 menunjukkan tanggapan responden tentang asosiasi merek secara keseluruhan, dan dapat dinyatakan bahwa asosiasi merek Biskuat pada anak di Kota Depok adalah positif yang terlihat dari mayoritas responden yaitu sebanyak 63 orang atau 63\% memiliki tanggapan terhadap asosiasi merek termasuk dalam kategori positif. Dalam hal ini, dapat dikatakan bahwa Biskuat mempunyai asosiasi yang benilai positif kepada anak-anak, sehingga apa yang ingin disampaikan oleh Biskuat dapat diterima baik oleh anak-anak dan membuat merek ini mempunyai asosiasi yang melekat di benak anak-anak.

Tabel 3. Kategorisasi Variabel Asosiasi Merek

\begin{tabular}{rccc}
\hline Sub Variabel & Kategori & $\begin{array}{c}\text { Frekuensi } \\
\text { (orang) }\end{array}$ & Persentase \\
\hline \multirow{3}{*}{ Asosiasi Merek $\left(X 1_{2}\right)$} & Positif & 63 & $63,00 \%$ \\
& Cukup Positif & 20 & $20,00 \%$ \\
& Kurang Positif & 17 & $17,00 \%$ \\
Total & & $\mathbf{1 0 0}$ & $\mathbf{1 0 0 , 0 0 \%}$ \\
\hline
\end{tabular}

Sumber : Hasil Pengolahan Data Penelitian

Tabel 4 menunjukkan tanggapan responden tentang kesan kualitas secara keseluruhan, dan dapat dinyatakan bahwa kesan kualitas Biskuat pada anak di Kota Depok adalah tinggi yang terlihat dari mayoritas responden yaitu sebanyak 64 orang atau 64\% memiliki tanggapan terhadap kesan kualitas termasuk dalam kategori tinggi. Dalam hal ini, Biskuat yang dari awal pemunculannya telah menempatkan diri sebagai biskuit yang terbuat dari gandum dan susu yang mengandung banyak vitamin dan mineral dipercaya dapat menambah asupan energi bagi anak. Kualitas ini dapat menjadi alasan bagi konsumen dalam melakukan pembelian, selain faktor-faktor lain yang ikut mempengaruhi keputusan ini. 
Tabel 4. Kategorisasi Variabel Kesan Kualitas

\begin{tabular}{rccc}
\hline Sub Variabel & Kategori & Frekuensi (orang) & Persentase \\
\hline \multirow{3}{*}{ Kesan Kualitas $\left(X 1_{3}\right)$} & Tinggi & 64 & $64,00 \%$ \\
& Cukup Tinggi & 28 & $28,00 \%$ \\
& Kurang Tinggi & 8 & $8,00 \%$ \\
& & $\mathbf{1 0 0}$ & $\mathbf{1 0 0 , 0 0 \%}$ \\
\hline
\end{tabular}

Sumber : Hasil Pengolahan Data Penelitian

Tabel 5 memperlihatkan tanggapan responden tentang kesetiaan merek secara keseluruhan, dan dapat dinyatakan bahwa kesetiaan merek Biskuat pada anak di Kota Depok adalah setia yang terlihat dari mayoritas responden yaitu sebanyak 50 orang atau 50\% memiliki tanggapan terhadap kesetiaan merek termasuk dalam kategori setia. Kesetiaan merek yang baik pada Biskuat menunjukkan bahwa konsumen telah mempercayai merek ini sebagai produk yang dipilih untuk memenuhi kebutuhan biskuitnya. Jika hal ini terus dijaga, tidak menutup kemungkinan suatu saat nanti anak-anak sebagai konsumen masa kini, akan menjadi future market di masa yang akan datang.

Tabel 5. Kategorisasi Variabel Kesetiaan Merek

\begin{tabular}{rccc}
\hline Sub Variabel & Kategori & $\begin{array}{c}\text { Frekuensi } \\
\text { (orang) }\end{array}$ & Persentase \\
\hline \multirow{2}{*}{ Kesetiaan Merek $\left(X 1_{4}\right)$} & Setia & 50 & $50,00 \%$ \\
& Cukup Setia & 42 & $42,00 \%$ \\
& Kurang Setia & 8 & $8,00 \%$ \\
Total & & $\mathbf{1 0 0}$ & $\mathbf{1 0 0 , 0 0 \%}$ \\
\hline
\end{tabular}

Sumber : Hasil Pengolahan Data Penelitian

Berdasarkan hasil tabulasi dan perhitungan setiap sub variabel ekuitas merek yang meliputi kesadaran merek, asosiasi merek, kesan kualitas, dan kesetiaan merek, dapat diperoleh kesimpulan mengenai tingkat ekuitas merek Biskuat oleh anak di Kota Depok yang terlihat pada ringkasan hasil perhitungan setiap sub variabel dalam Tabel 6. 
Tabel 6. Kategorisasi Positif Variabel Ekuitas Merek

\begin{tabular}{cccc}
\hline Sub Variabel & Kategori & $\begin{array}{c}\text { Frekuensi } \\
\text { (orang) }\end{array}$ & Persentase \\
\hline Kesadaran Merek & Tinggi & 68 & $68 \%$ \\
Asosiasi Merek & Positif & 63 & $63 \%$ \\
Kesan Kualitas & Tinggi & 64 & $64 \%$ \\
Kesetiaan Merek & Setia & 50 & $50 \%$ \\
\hline
\end{tabular}

Sumber : Hasil Pengolahan Data Penelitian

Berdasarkan Tabel 6, dapat disimpulkan bahwa ekuitas merek Biskuat pada anak di Kota Depok adalah cukup kuat yang terlihat dari frekuensi dan persentase responden pada setiap sub variabel di atas adalah $\geq 50$ orang, sehingga dapat dikatakan bahwa mayoritas responden anak ini setuju bahwa ekuitas merek Biskuat yang tercermin dalam kesadaran merek, asosiasi merek, kesan kualitas, dan kesetiaan merek ini adalah cukup kuat.

Persepsi mengenai biskuit ini telah dibangun melalui jalur merek "Biskuat", dan hasil dari keempat sub variable ekuitas merek Biskuat ini cukup untuk menggambarkan bagaimana ekuitas merek Biskuat ini tertanam di benak anakanak. Suatu produk dengan ekuitas merek yang kuat dapat membentuk landasan merek yang kuat pula dan mampu mengembangkan keberadaan suatu merek dalam persaingan apa pun dalam jangka waktu yang lama. Semakin kuat ekuitas merek suatu produk, semakin kuat daya tariknya untuk menggiring konsumen mengkonsumsi produk tersebut. Mengelola ekuitas merek dapat meningkatkan keunggulan bersaing. Karena itu, perusahaan yang memiliki merek yang kuat dapat lebih mudah merebut bisnis yang ada dibandingkan perusahaan yang tidak memiliki merek yang kuat.

Berdasarkan perhitungan dan kategorisasi setiap sub variabel ekuitas merek di atas, tidak semua anak menjawab positif atas pernyataan-pernyataan dalam kuesioner yang diajukan. Hal ini dikarenakan anak-anak mempunyai penilaian yang berbeda-beda terhadap Biskuat dan mereka pun mempunyai preferensi sendiri terhadap merek yang mereka sukai. Walaupun mayoritas responden anak menyatakan kepositifannya terhadap Biskuat, anak-anak yang member respon negatif terhadap Biskuat ini pun layak menjadi perhatian. 
Tabel 7. Kategorisasi Variabel Keputusan Pembelian

\begin{tabular}{cccc}
\hline Variabel & Kategori & Frekuensi (orang) & Persentase \\
\hline & $\begin{array}{c}\text { Preferensi } \\
\text { Tinggi }\end{array}$ & 52 & $52,00 \%$ \\
$\begin{array}{c}\text { Keputusan Pembelian } \\
(Y)\end{array}$ & $\begin{array}{c}\text { Preferensi } \\
\text { Cukup Tinggi } \\
\text { Preferensi } \\
\text { Kurang Tinggi }\end{array}$ & 40 & $40,00 \%$ \\
Total & & $\mathbf{1 0 0}$ & $\mathbf{1 0 0 , 0 0 \%}$ \\
\hline
\end{tabular}

Sumber : Hasil Pengolahan Data Penelitian

Berdasarkan Tabel 7 dapat diketahui tanggapan responden tentang keputusan pembelian secara keseluruhan, dan dapat dinyatakan bahwa keputusan pembelian Biskuat pada anak di Kota Depok mempunyai preferensi tinggi dalam membeli Biskuat yang terlihat dari mayoritas responden yaitu sebanyak 52 orang atau 52\% responden memiliki tanggapan terhadap keputusan pembelian termasuk dalam kategori berpreferensi tinggi. Keputusan pembelian yang dilakukan oleh anak-anak di atas membuktikan bahwa anak-anak telah melakukan sosialisasi konsumen, di mana hal ini timbul karena adanya sejumlah pendapatan, termasuk periklanan dan pertemanan. Bagaimanapun, keluarga adalah sumber utama dari sosialisasi konsumen ini (Hawkins dan Mothersbaugh, 2010). Gambaran keputusan pembelian Biskuat di atas memperlihatkan bahwa anak-anak telah mempunyai consumer skills, di mana anak-anak mempunyai kemampuan dalam pembelian untuk memahami uang, budgeting, evaluasi produk, dan lainnya. Pada tahap ini, anak-anak sudah melakukan pembelian secara mandiri sejalan dengan kemampuannya untuk mengunjungi toko dan memilih sesuatu yang diinginkannya tanpa orang tua. Di sinilah anak-anak berperan sebagai primary market.

Hasil empiris yang telah dilakukan memperoleh nilai koefisien korelasi yang menggambarkan besarnya hubungan antar variabel, yaitu: Pertama, variabel kesadaran merek (X11) mempunyai hubungan sebesar 0,584 atau 58,4\% dengan keputusan pembelian. Ini disebabkan karena anak-anak memiki kemampuan dalam mengenali merek-merek tertentu, terutama yang "eye catching” bagi mereka. Kedua, variabel asosiasi merek ( $\left.\mathrm{X}_{2}\right)$ mempunyai hubungan sebesar 0,493 atau 49,3\% dengan keputusan pembelian. Ini disebabkan karena asosiasi merek yang 
dimiliki oleh Biskuat mempunyai gambaran yang kuat di benak anak-anak. Ketiga, variabel kesan kualitas $\left(\mathrm{X} 1_{3}\right)$ mempunyai hubungan sebesar 0,551 atau 55,1\% dengan keputusan pembelian. Ini disebabkan karena pengetahuan anak mengenai kualitas merek tertentu dipengaruhi oleh orang tua dan lingkungan sosialnya dalam memilih produk yang berkualitas. Keempat, variabel kesetiaan merek $\left(\mathrm{X}_{4}\right)$ mempunyai hubungan sebesar 0,411 atau 44,1\% dengan keputusan pembelian. Ini disebabkan karena anak-anak cenderung memiliki loyalitas yang rendah terhadap merek terentu.

Untuk menguji apakah dimensi-dimensi variabel ekuitas merek secara bersama-sama berpengaruh terhadap keputusan pembelian digunakan statistik Uji F. Berdasarkan tabel ANOVA, dapat dilihat bahwa F hitung $>\mathrm{F}$ tabel $(33,872>2,467)$ sehingga sesuai dengan kriteria uji simultan adalah tolak $\mathrm{H}_{0}$, artinya ekuitas merek yaitu kesadaran merek, asosiai merek, kesan kualitas, dan kesetiaan merek secara simultan (bersama-sama) berpengaruh terhadap keputusan pembelian.

Uji parsial dilakukan untuk melihat variabel eksogen mana saja yang berpengaruh terhadap variabel endogen. Uji statistik yang digunakan pada pengujian secara individual masing-masing variabel adalah statistic Uji-t. Berdasarkan pengujian yang telah dilakukan, dapat diperoleh kesimpulan dalam pengujian hipotesis secara parsial pada Tabel 8.

Tabel 8. Pengujian Hipotesis Parsial

\begin{tabular}{llll}
\hline Koefisien Jalur & t-hitung & t-tabel & Kesimpulan \\
\hline $\mathrm{X} 1_{1}=0.388$ & 5.466 & 1.985 & Ho Ditolak \\
$\mathrm{X} 1_{2}=0.241$ & 3.352 & 1.985 & Ho Ditolak \\
$\mathrm{X} 1_{3}=0.306$ & 4.150 & 1.985 & Ho Ditolak \\
$\mathrm{X} 1_{4}=0.179$ & 2.548 & 1.985 & Ho Ditolak \\
\hline
\end{tabular}

Sumber: Data Primer (diolah)

Berdasarkan perhitungan analisis jalur, maka diperoleh kerangka hubungan kausal empiris antara jalur ( $\mathrm{X} 1_{1}$ terhadap $\mathrm{Y}, \mathrm{X} 1_{2}$ terhadap $\mathrm{Y}$ dan $\mathrm{X} 1_{1}, \mathrm{X} 1_{2}$ terhadap $\mathrm{Y}$ ) dapat dibuat melalui persamaan struktural berikut ini : 


$$
\begin{gathered}
\mathrm{Y}=\rho_{\mathrm{yx} 1} \mathrm{X} 1_{1}+\rho_{\mathrm{yx} 2} \mathrm{X} 1_{2}+\rho_{\mathrm{yx} 2} \mathrm{X} 1_{3}+\rho_{\mathrm{yx} 2} \mathrm{X} 1_{4}+\rho_{\mathrm{y} \varepsilon} \\
\mathrm{Y}=0.388 \mathrm{X}_{1}+0.241 \mathrm{X}_{2}+0.306 \mathrm{X}_{3}+0.179 \mathrm{X}_{4}+0.412 \varepsilon
\end{gathered}
$$

Berdasarkan hasil penelitian, diperoleh kesimpulan yaitu terdapat pengaruh antara Kesadaran Merek (X11), Asosiasi Merek (X12), Kesan Kualitas (X13) dan Kesetiaan Merek (X14) terhadap Keputusan Pembelian (Y). Untuk melihat lebih jauh tentang besar pengaruh langsung dan tidak langsung dari masing-masing variabel bebas terhadap variabel terikat, sehingga secara statistik dinyatakan berpengaruh, berikut disajikan rincian pengaruh langsung dan tidak langsungnya.

Gambar 2. Diagram Analisis Jalur

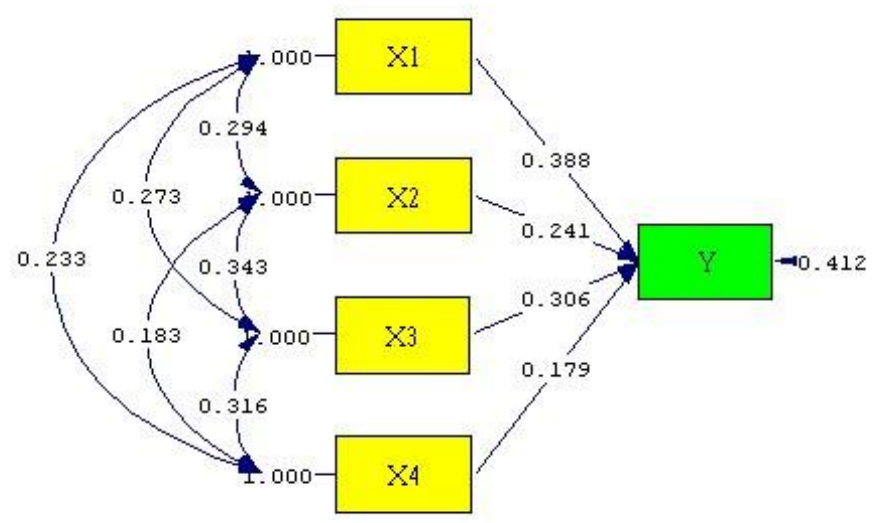

\begin{tabular}{|c|c|c|c|c|c|c|c|c|}
\hline \multirow[t]{2}{*}{$\begin{array}{l}\text { Sub } \\
\text { Var }\end{array}$} & \multirow[t]{2}{*}{$\begin{array}{c}\text { Koefisien } \\
\text { Jalur }\end{array}$} & \multirow[t]{2}{*}{$\begin{array}{l}\text { Pengaruh } \\
\text { Langsung }\end{array}$} & \multicolumn{4}{|c|}{$\begin{array}{c}\text { Pengaruh tidak } \\
\text { langsung (melalui), } \\
\text { dalam \% }\end{array}$} & \multirow{2}{*}{$\begin{array}{l}\text { Pengaruh } \\
\text { Tdk } \\
\text { Langsung }\end{array}$} & \multirow[t]{2}{*}{$\begin{array}{c}\text { Total } \\
(\%)\end{array}$} \\
\hline & & & $\mathbf{X} 1_{1}$ & $\mathbf{X} \mathbf{1}_{2}$ & $\mathbf{X} 1_{3}$ & $\mathbf{X} 1_{4}$ & & \\
\hline $\mathbf{X 1} 1$ & 0.388 & 15.05 & - & 2.75 & 3.24 & 1.62 & 7.61 & 22.66 \\
\hline $\mathbf{X} 1_{2}$ & 0.241 & 5.82 & 2.75 & - & 2.53 & 0.79 & 6.07 & 11.89 \\
\hline $\mathbf{X} \mathbf{1}_{3}$ & 0.306 & 9.36 & 3.24 & 2.53 & - & 1.73 & 7.50 & 16.86 \\
\hline$X 1_{4}$ & 0.179 & 3.22 & 1.62 & 0.79 & 1.73 & - & 4.15 & 7.37 \\
\hline
\end{tabular}

Tabel 9. Pengaruh Variabel Bebas (X) terhadap Keputusan Pembelian (Y)

\section{Sumber: Data Primer (diolah)}

Kesadaran Merek (X11) berpengaruh terhadap Keputusan Pembelian (Y), sebagaimana telah di sajikan pada uji-t dengan total pengaruh sebesar $22,66 \%$, terdiri atas pengaruh langsung sebesar $15.05 \%$ dan pengaruh tidak langsung 
sebesar 7.61\%. Asosiasi Merek (X12) berpengaruh terhadap Keputusan Pembelian $(\mathrm{Y})$, sebagaimana telah disajikan pada uji-t dengan total pengaruh sebesar $11.89 \%$, terdiri atas pengaruh langsung sebesar $5.82 \%$ dan pengaruh tidak langsung sebesar 6.07\%. Kesan Kualitas (X13) berpengaruh terhadap Keputusan Pembelian (Y), sebagaimana telah di sajikan pada uji-t dengan total pengaruh sebesar $16.86 \%$, terdiri atas pengaruh langsung sebesar $9.36 \%$ dan pengaruh tidak langsung sebesar 7.50\%. Kesetiaan Merek (X14) berpengaruh terhadap Keputusan Pembelian (Y), sebagaimana telah di sajikan pada uji-t dengan total pengaruh sebesar $7.37 \%$, terdiri atas pengaruh langsung sebesar 3,22\% dan pengaruh tidak langsung sebesar 4.15\%. Kesadaran merek ( $\left.\mathrm{X} 1_{1}\right)$, asosiasi merek $\left(\mathrm{X} 1_{2}\right)$, kesan kualitas $\left(\mathrm{X} 1_{3}\right)$, dan kesetiaan merek $\left(\mathrm{X}_{4}\right)$ berpengaruh secara simultan terhadap keputusan pembelian (Y) sebesar 58.8\%. Sisanya yaitu sebesar $41.2 \%$ dipengaruhi oleh faktor lain di luar variabel yang diteliti.

Hasil penelitian secara individual menunjukkan bahwa variabel kesadaran merek yang diukur memiliki pengaruh terhadap keputusan pembelian Biskuat. Besarnya kontribusi variabel tersebut terhadap keputusan pembelian adalah 22.66\%. Variabel ini adalah yang paling dominan di antara variabel yang lain karena kesadaran mereklah yang membuat anak-anak mengenali produk tersebut. Semakin sering produsen melakukan kegiatan yang meningkatkan kesadaran mereknya, semakin kenal pula konsumen terhadap produk yang ditawarkan. Merek ini mempunyai pengaruh yang kuat dalam perilaku anak, dan nama merek adalah atribut yang paling khas dalam permintaan pembelian oleh anak-anak diantara berbagai macam tipe makanan yang sering mereka nikmati (Fan dan Li, 2010). Berdasarkan hasil perhitungan koefisien jalur di atas, kesadaran merek Biskuat mudah diingat oleh anak sehingga faktor ini secara langsung dapat mempengaruhi keputusan pembeliannya.

Besarnya kontribusi variabel asosiasi merek terhadap keputusan pembelian pada Tabel 9 adalah sebesar 11.89\%. Hal ini menunjukkan kontribusi asosiasi merek terhadap keputusan pembelian secara langsung tidak begitu besar. Walaupun kontribusinya tidak dominan dalam melakukan keputusan pembelian, asosiasi merek ini harus tetap diperhatikan dan harus tetap mempunyai nilai positif, 
karena hal ini akan memberikan banyak value, antara lain dapat memudahkan pelanggan untuk mendapatkan informasi tentang merek, mempengaruhi interpretasi pelanggan atas fakta mengenai merek, membedakan merek dari merek pesaing, memperkuat posisi merek di pasar, dapat menjadi alasan bagi pelanggan untuk menggunakan merek, dan bagi perusahaan dapat menjadi dasar untuk melakukan perluasan merek (Aaker, 1991).

Variabel kesan kualitas memberikan kontribusi secara langsung sebesar $16.86 \%$ terhadap keputusan pembelian. Besar kontribusi ini juga tidak dominan, namun kesan kualitas akan berpengaruh langsung pada keputusan pembelian dan loyalitas merek (Aaker, 1991). Jika persepsi pelanggan terhadap kualitas keseluruhan jelek, sebesar apapun usaha perusahaan untuk mempengaruhi pelanggan dalam keputusan pembelian dan menciptakan loyalitas terhadap produk cenderung tidak akan berhasil. Oleh karena itu produk harus mempunyai suatu keunggulan yang berhubungan dengan tujuan yang diinginkan.

Kontribusi yang diberikan oleh variabel kesetiaan merek terhadap keputusan pembelian adalah sebesar 7.37\%. Secara umum, kesetiaan merek di kalangan anak-anak masih relatif rendah dikarenakan kecenderungan mereka yang masih tertarik dengan hal-hal yang baru dan tingkat keingintahuan mereka dalam banyak hal termasuk dalam konsumsi makanan, dalam hal ini produk biskuit. Namun, sejalan dengan kualitas, jika konsumen merasakan kualitas yang nyata pada suatu produk, maka pengalaman ini akan membuat konsumen melakukan pembelian ulang dan apabila terjadi secara konsisten akan meningkatakan loyalitas terhadap merek tersebut.

Berdasarkan hasil pengujian, dapat dilihat bahwa secara simultan, kesadaran merek, asosiasi merek, kesan kualitas, dan kesetiaan merek berpengaruh langsung terhadap keputusan pembelian yang dilakukan oleh anak usia sekolah dasar di Kota Depok sebesar 58.8\%. Sisanya yaitu 41.2\% merupakan pengaruh yang datang dari faktor-faktor lain. Hal ini ditunjukkan oleh hasil perhitungan dengan analisis jalur (path analysis) dari uji F dengan nilai sebesar 33.872 yang signifikan pada tingkat $\alpha=0,05$ dan positif sehingga terdapat hubungan yang positif terhadap keputusan pembelian. Semakin tinggi tingkat ekuitas merek maka semakin tinggi 
pula tingkat keputusan pembeliannya.

Apabila tingkat ekuitas merek Biskuat pada anak-anak di Kota Depok mengalami kenaikan maka keputusan pembeliannya juga mengalami kenaikan. Demikian juga sebaliknya, apabila tingkat ekuitas merek Biskuat pada anak-anak di Kota Depok mengalami penurunan maka keputusan pembeliannya juga akan mengalami penurunan. Dengan demikian, maka ekuitas merek Biskuat yang digambarkan oleh kesadaran merek, asosiasi merek, kesan kualitas, dan kesetiaan merek memiliki pengaruh terhadap keputusan pembelian yang dilakukan oleh anak usia sekolah dasar di Kota Depok, baik secara parsial maupun secara simultan.

\section{Pembahasan}

Semakin berkembangnya bidang studi mengenai anak-anak sebagai konsumen maupun marketing pada anak-anak, membuat bidang ini menjadi tidak asing lagi untuk dibahas. Sudah banyak penelitian yang dilakukan oleh para ahli, artikel-artikel yang dipublikasikan, dan buku-buku yang ditebitkan menempatkan bidang ini sebagai ilmu yang relevan perilaku konsumen (Consumer Behavior). Seiiring dengan perkembangan zaman, kemajuan teknologi, perubahan trend dalam tatanan social menempatkan anak-anak menjadi konsumen yang tidak bisa diacuhkan. Sosialisasi konsumen timbul karena adanya sejumlah pendapatan, termasuk periklanan dan pertemanan. Bagaimanapun, keluarga adalah sumber utama dari sosialisasi konsumen (Hawkins dan Mothersbaugh, 2010: 215). Baik Hawkins dan Mothersbaugh (2010); Schiffman dan Kanuk (2010) mendefinisikan sosialisasi konsumen sama dengan yang diungkapkan oleh Ward (1974) yaitu, sosialisasi konsumen ialah proses dimana anak-anak muda memperoleh kemampuan, pengetahuan, dan tingkah laku yang relevan dengan fungsinya sebagai konsumen di marketplace.

Menurut Hawkins dan Mothersbaugh (2010), mereka memberikan perhatian pada pemahaman mengenai konten dari sosialisasi konsumen dan proses sosialisasi konsumen itu sendiri. Konten dari sosialisasi konsumen mengacu pada apa yang anak-anak pelajari berkaitan dengan konsumsi dan proses bagaimana mereka mempelajarinya. Anak-anak mempunyai kemampuan yang berbeda-beda sesuai dengan usianya dalam mempelajari tentang konsumsi. Kemampuan mereka 
terbatas dalam memproses berbagai macam informasi.

Peranan anak yang cukup besar dalam memilih berbagai produk yang mereka inginkan ini membuat para marketer semakin mengedepankan produknya dengan membangun merek yang relatif mudah dikenali dan diterima oleh anakanak. Semakin anak-anak mengenal merek produk tersebut, semakin besar pula kecenderungan mereka memilih produk tersebut dan melakukan pembelian. Merek adalah salah satu faktor terpenting yang bisa mempengaruhi anak-anak dalam mengambil keputusan untuk membeli dan anak-anak mempunyai respons tersendiri terhadap merek-merek yang dijumpainya. Dalam penelitian mengenai perilaku pembelian oleh anak-anak (Fan dan Li, 2010) menyatakan bahwa merek mempunyai pengaruh yang kuat dalam perilaku pasar anak dan nama merek adalah atribut yang paling khas dalam permintaan pembelian oleh anak-anak diantara berbagai macam tipe makanan yang mereka sering gunakan dan mereka nikmati.

Anak-anak cenderung hanya membeli produk yang mereknya sudah mereka kenal. Mereka dengan mudah bisa mengingat merek yang mereka suka melalui warna, rasa, karakter, tokoh, dan lain-lain. Sebelum mereka bisa membaca pun anak-anak usia dua atau tiga tahun bisa mengenali kemasan yang familiar di toko dan karakter yang familiar pada produk seperti mainan dan makanan (John, 1999). Seiiring perkembangannya, kesadaran merek pada anak-anak menjadi suatu nyata. Kesadaran anak-anak dan penyebutan nama merek yang berulang-ulang meningkat di usia awal sampai pertengahan masa anak-anak dan kesadaran merek pada anak-anak ini pertama kali berkembang pada kategori-kategori produk yang berorientasi anak-anak, seperti sereal, makanan ringan, dan mainan. Fakta ini menunjukkan betapa pentingnya marketer harus berusaha untuk membangun mereknya di pasar anak-anak, karena anak kini tidak lagi bisa dianggap sebagai konsumen yang pasif. Mereka semakin memiliki aspirasi sendiri dan lebih mempunyai pemahaman dalam mengenali persamaan dan perbedaan diantara berbagai macam merek.

Berdasarkan pengamatan dan wawancara dengan sejumlah anak mengenai Biskuat, mereka memiliki jawaban yang beragam dan alasan yang berbeda-beda dalam membeli Biskuat. Ada yang menjawab karena tertarik dengan hadiahnya, 
yaitu bertemu dan bisa berlatih langsung dengan bintang sepak bola favorit mereka. Namun, ada juga yang memberikan alasan karena harga Biskuat yang relatif murah, rasa yang enak (seperti susu), dan juga agar bertambah energinya. Jawabanjawaban ini tidak bisa langsung ditarik kesimpulan karena diperlukan penelitian lanjut untuk melihat kcenderungan mereka dalam membeli biskuit. Namun hal ini telah mengindikasikan bahwa anak-anak sudah memiliki pilihan dan preferensi sendiri dalam memilih merek dan apa yang membuatnya tertarik. Walaupun mereka tidak memahami ekuitas merek, dengan apa yang mereka lakukan dalam suatu proses pembelian, dapat terlihat sebenarnya mereka sudah memberikan penilaian sendiri terhadap ekuitas merek dengan cara yang dipahaminya.

Merek tidak hanya memberikan identitas bagi produk tetapi merupakan sesuatu hal yang bisa memberikan suatu kebanggaan bahkan fanatisme sehingga merek yang terpercaya diyakini mampu meningkatkan kekuatan ekuitas dari merek tersebut. Saat ini merek bukan hanya simbol atau sekedar nama saja. Merek memiliki arti penting yang lain yakni dapat menggambarkan produk, pelayanan, distribusi, bahkan perusahaan. Merek dapat memberikan image tersendiri. Image mengenai suatu merek dapat terbentuk dari hasil persepsi seseorang terhadap suatu merek tertentu berdasarkan pengalamannya, informasi dari teman ataupun informasi komersial yang didapatkan dari media massa. Oleh karena itulah peranan ekuitas merek dapat memberikan rasa keterikatan kepada konsumen, dalam hal ini anak-anak sehingga dapat mempengaruhi pengambilan keputusan pembelian anak kepada orang tua sebagai pengambil keputusan utama.

Cara pandang anak terhadap ekuitas merek tersebut berbeda dengan orang dewasa yang menilai dan memilih merek dengan lebih kompleks. Orang dewasa cenderung mencari informasi dan melakukan observasi terlebih dahulu terhadap merek yang akan ia pilih. Anak-anak dengan karakternya lebih sederhana memandang dan memilih merek sesuai dengan asosiasi mereka sendiri, respon sosial, dan marketing stimuli disekitarnya.

Dalam upaya membangun dan mempertahankan ekuitas merek yang dicerminkan dalam kesadaran merek, asosiasi merek, kesan kualitas, dan kesetiaan merek di kalangan anak-anak, diperlukan upaya yang kontinyu dan 
berkesinambungan agar merek tetap terjaga, bertahan, bahkan tetap memiliki keunggulan bersaing. Hal ini tidak lepas dari upaya produsen dalam melakukan inovasi-inovasi baru, meningkatkan kreativitasnya dalam membangun merek terutama pada anak-anak yang mempunyai kecenderungan mudah bosan terhadap merek atau item tertentu. Peluasan merek dapat juga dilakukan dengan catatan produk yang menjadi unggulan tetap diutamakan. Hendaknya produsen juga dapat mengadakan kegiatan yang akan memberikan pengalaman kepada ibu dari anakanak sebagai role model utama bagi anak-anak, karena pengaruh ibu cukup besar bagi anak-anak sebagai penentu hal-hal apa saja yang boleh dibeli/dikonsumsi oleh anak karena orang tua memiliki kecenderungan ingin anaknya mendapatkan yang terbaik. Dengan bekal ilmu dan pengalaman yang dimiliki oleh anak terhadap jenis produk dan merek tertentu, maka hal itu akan mempengaruhinya dalam melakukan keputusan pembelian produk/merek tersebut.

Senantiasa untuk berkomunikasi dengan anak-anak sebagai target konsumen, misalnya dengan mengadakan acara yang melibatkan anak-anak sehingga anak-anak mendapatkan pengalaman tersendiri dengan merek tersebut dan sekaligus sebagai publisitas bagi merek itu sendiri. Melalui komunikasi dan berinteraksi akan menimbulkan keterikatan emosional antara anak dan merek sehingga dapat mempengaruhinya dalam melakukan keputusan pembelian.

\section{SIMPULAN}

Ekuitas merek yang dicerminkan oleh kesadaran merek, asosiasi merek, kesan kualitas, dan kesetiaan merek di Kota Depok adalah cukup kuat, dengan tingkat kesadaran merek yang tinggi, tingkat asosiasi merek yang positif, tingkat kesan kualitas yang tinggi, dan tingkat kesetiaan merek yang setia. Keputusan pembelian yang dilihat dari frekuensi pada masing-masing variabel juga masuk dalam kategori berpreferensi tinggi. Hal ini terlihat sejalan dengan ekuitas merek yang cukup kuat dapat mendukung tingkat keputusan pembelian yang berpreferensi tinggi pula.

Ekuitas merek yaitu kesadaran merek, asosiai merek, kesan kualitas, dan kesetiaan merek secara simultan (bersama-sama) berpengaruh cukup besar terhadap keputusan pembelian yaitu sebesar 58,88\% . Kesadaran Merek $\left(\mathrm{X}_{1}\right)$ 
berpengaruh terhadap Keputusan Pembelian (Y), sebesar 22,66\% dengan arah yang positif. Asosiasi Merek $\left(\mathrm{X}_{2}\right)$ berpengaruh terhadap Keputusan Pembelian (Y), sebesar $11,89 \%$ dengan arah yang positif. Kesan Kualitas $\left(\mathrm{X}_{3}\right)$ berpengaruh terhadap Keputusan Pembelian (Y), sebesar 16,86\% dengan arah yang positif. Kesetiaan Merek $\left(\mathrm{X}_{4}\right)$ berpengaruh terhadap Keputusan Pembelian (Y), sebesar $7,37 \%$ dengan arah yang positif.

\section{PUSTAKA ACUAN}

Aaker, D.A. (1991). Managing Brand Equit : Capitalizing on The value of A Brand Name. New York: The Press.

Dotson, M.F. \& E.M. Hyatt. (2005). Major Influence Factors in Children's Consumer Socialization. Journal of Consumer Marketing, Vol. 22, No.1: 35-42

Fan, Y. \& Y. Li. (2010). Children's Buying Behavior in China. Journal of Marketing Intelligence \& Planning. Vol. 28, No.2: 170-187

Hawkins, D.I. \& D.L. Mothersbaugh. (2010). Consumer Behavior: Building Marketing Strategy. Eleventh Edition. New York: McGraw Hill.

John, D.R. (1999). Consumer Socialization of Children: A Retrospective Look at Twenty-Five Years of Research. The Journal of Consumer Research, Vol. 26, No. 3: 183-213.

Lindstorm, M. (2007). Brandchild. London: Kogan-Page

McNeal, J.U. (1992). Kids as Customers: A Handbook of Marketing to Children. Oxford: Lexington Books.

Riduwan. (2009). Metode dan Teknik Menyusun Proposal Penelitian. Bandung: Alfabeta.

Ross, J. \& R. Harradine. (2004). I'm not wearing that! Branding and Young Children. Journal of Fashion Marketing and Management, Vol. 8, No.1: 11-25.

Schiffman, L.G. \& L.L Kanuk. (2010). Consumer Behavior. (10 th ed). New Jersey: Prentice Hall.

Sugiyono. (2011). Statistika untuk Penelitian. Bandung: Alfabeta.

Ward, S. (1974). Consumer Socialization. Journal of Consumer Research. Vol.1, No.2: 1-14. 